\title{
Finansal Başarısızlığın Oran Analizi ve Diskriminant Analizi Kullanılarak Ölçümlenmesi: BİST’de İşlem Gören Dokuma, Giyim Eşyası ve Deri İşletmeleri Üzerine Bir Araştırma *
}

\author{
Seval SELIMOĞLU** \\ Abdullah ORHAN***
}

\section{$\ddot{O Z Z E T}$}

Finansal başarısızlık, uzun yıllardır işletmeler, yatırımcılar ve kredi verenler açısından en önemli risklerden biri olmuştur. Son yillarda küreselleşmenin, teknolojik gelişmelerin ve ekonomik şartların etkisiyle hem ulusal hem de uluslararası piyasaların hızla değişmekte ve gelişmekte olduğu gözlemlenmektedir. Bu değişim ve geliş̧im, özellikle işletmeler açısından, finansal başarısızlıkları öngörmeyi ön plana çıkarmaktadır.

Bu çalışmanın amacı, Borsa İstanbul'da işlem gören dokuma, giyim eşyası ve deri işletmelerinin finansal başarısıllıklarının ölçümlenmesinde yararlanilabilecek finansal oranları belirlemektir. 23 adet finansal oran kullanılarak yapılan çok değişkenli analiz sonucunda 7 finansal oranın gruplar arasında anlamlı farklılık gösterdiği tespit edilmiştir. Bu 7 oran kullanılarak yapılan diskriminant analizi sonucunda, kullanılan modelin \%92 sınıflandırma başarısı gösterdiği belirlenmişstir.

Anahtar Kelimeler: Finansal Başarısızlık, Finansal Başarısızlık Tahmini, Diskriminant Analizi, Oran Analizi, Türk Tekstil Sektörü, Mann-Whitney U Testi.

JEL Sınıflandırması: M40, M41, C38.

Measuring Business Failure by Using Ratio Analysis and Discriminant Analysis: A Research on Textile, Clothes and Leather Firms Listed In The Istanbul Stock Exchange

\section{ABSTRACT}

Business failure has been one of the most important risks for companies, investors and creditors for long years. Local and international markets have been developing and changing with the effect of globalization, technological development and economic conditions during recent years. This change and development make forecasting of business failure foregrounding especially for companies.

The purpose of this paper to find out financial ratios that might be useful to measure business failure of companies which operate in textile, clothes and leather sector. 23 financial ratios were used for multivariate analysis and as a result; 7 of these ratios are found they differentiate between groups. By employing these 7 ratios to discriminant analysis, we found out our model has $92 \%$ accuracy.

Keywords: Business Failure, Predicting Business Failure, Discriminant Analysis, Ratio Analysis, Turkish Textile Sector, Mann-Whitney U Test.

Jel Classification: M40, M41, C38.

\footnotetext{
* Bu araştırma "Finansal Başarısızlığın Oran Analizi ve Diskriminant Analizi Kullanılarak Ölçümlenmesi: BİST'de İşlem Gören Dokuma, Giyim Eşyası ve Deri İşletmeleri Üzerine Bir Araştırma” adlı yüksek lisans tezinden türetilmiştir.

** Prof. Dr. Seval Selimoğlu, Anadolu Üniversitesi, İktisadi ve İdari Bilimler Fakültesi sselimoglu@anadolu.edu.tr

*** Araş. Gör. Abdullah Orhan, Anadolu Üniversitesi, İktisadi ve İdari Bilimler Fakültesi abdullahorhan@anadolu.edu.tr
} 


\section{GíRiş}

Finansal başarısızlığın ölçümlenmesi uzun zamandır üzerinde çalışılan bir konu olmuştur. Ticari anlamda sınırların neredeyse ortadan kalkmış olduğu günümüzde işletmeler dünyanın her yerinden yatırımc1, müşteri ve rakiplerle muhatap olmaktadır. Bu durum da işletmeleri bir belirsizlik ortamına sürüklemektedir. Belirsizlik ortamlarında finansal başarısızlı̆̆ın öngörülmesi daha karmaşı bir durum haline gelmekte ve daha fazla önem kazanmaktadır. Finansal başarısızlı̆ıı erken belirlenmesi ve bu duruma mümkün olduğu kadar erken müdahale edilmesi finansal başarısızlığın işletme üzerindeki etkilerini en aza indirebilir. Bu durumla paralel olarak, yatırımcılar ve kredi verenler de işletmelere yatırım yapma ve kredi verme konularını değerlendirirken finansal başarısızlık riskini dikkate alarak yatırımın değer kaybetmesi ya da alacakların tahsil edilememesi risklerini azaltabilirler.

Ülkemizdeki en büyük ikinci sektör olan dokuma, giyim eşyası ve deri sektöründeki işletmelerin finansal başarısızlıklarının ölçümlenmesi oldukça yüksek derecede önem taşımaktadır. Zira imalat sanayii katma değerinin $\% 16,4^{\prime}$ ü ve toplam ülke katma değerinin $\% 5,5$ 'i dokuma, giyim eşyası ve deri sektöründe üretilmektedir. (Sanayi Genel Müdürlüğü, 2013: 6-7) Ortalama 60 milyar dolar ciro, 27 milyar dolar ihracat ve yaklaşı 1 milyon kayıtlı istihdamla ülke ekonomisinde büyük yeri olan dokuma, hazır giyim ve deri sektörü işletmelerinden hisseleri borsada işlem gören sadece 27 işletme vardır. Bu durum da ilgili sektörde faaliyet gösteren işletmelerin büyük çoğunluğunun küçük ve orta büyüklükte işletmeler ile şahıs şirketleri olduğunu göstermektedir.

Kurumsallaşamayan işletmelerin rekabet güçlerinin zamanla düştüğü ve faaliyetlerine uzun süre devam edemedikleri bilinmektedir. Bununla birlikte Çin'in yaklaşık 246 milyar dolar ihracatla tekstil ve hazır giyim ihracatçıları arasında açık ara farkla lider olması tüm ülkelerde olduğu gibi ülkemizdeki işletmeleri de etkilemektedir. Rekabet gücü düşen işletmelerin finansal yapıları zamanla bozulmakta ve finansal başarısızlık sinyalleri vermektedirler.

İşletmelerin finansal yapılarının ne derece güçlü olduğunun ölçülmesinde finansal analiz tekniklerinden yararlanılır. Yatırımcılar ve kredi verenler işletmelerin finansal tablolarını çeşitli analiz teknikleri ile inceleyerek işletmeye yatırım yapma ve kredi verme konularında karar vermeye çalışılar. Aynı zamanda işletme sahipleri ve yöneticileri de finansal tabloları inceleyerek işletmenin mevcut durumunu değerlendirir ve gelecek ile ilgili stratejik kararlarını bu değerlendirmeler sonucunda şekillendirirler.

Finansal oranlar, finansal tablolardaki sayısal verilerden elde edilir ve işletmenin mevcut durumu hakkında bilgi verirler. Tutarlardan ve miktarlardan arındırılmış oldukları için işletmenin mevcut durumunu, geçmiş dönemleriyle ve diğer işletmelerle kıyaslama olanağ 1 sunarlar.

Finansal başarısızlığın ölçümlenmesinde finansal oranlar 1966 yılından beri kullanılmaktadır. (Beaver, 1966: 71-111) Finansal oranlar çeşitli analiz yöntemleri 
kullanılarak incelenir ve finansal başarısızlık riski belirlenir. Teknolojideki ve istatistiki tekniklerdeki gelişmelere bağlı olarak finansal başarısızlık ölçümleme modelleri de gün geçtikçe gelişmekte ve çeşitlenmektedir.

Bu çalışmanın amacı, hisseleri BİST’de işlem gören Dokuma, Giyim Eşyası ve Deri İşletmelerinin finansal başarısızlıklarının ölçümlenmesi için güvenilir bir model oluşturmaktır. Bu amaçla, öncelikle finansal başarısızlık kavramı ele alınmıştır. Daha sonra oran analizi ve diskriminant analizi tekniklerinin finansal başarısızlığın belirlenmesinde birlikte kullanılması konusu teorik olarak açıklanmıştır. Son kısımda ise finansal oranlar ve finansal başarısızlık arasındaki ilişkiyi ortaya koymak üzere BİST'de işlem gören Dokuma, Giyim Eşyası ve Deri İşletmelerinin finansal oranları IBM SPSS Statistics 21 programı ile analiz edilerek değerlendirilmiştir.

\section{ALANYAZIN}

Finansal başarısızlık, elli yıla yakın bir süredir çeşitli çalışmalara konu olmuştur. Bu konu hakkında yapılmış ilk çalışma Beaver' in 1966 yılında yapmış olduğu çalışmadır. Beaver (1966) çalışmasında 30 finansal oranı altı grup altında toplamış ve her bir oran için tekli diskriminant analizi uygulamıştır. Çalışma sonucunda nakit akışı/borç toplamı oranının finansal başarısızlığın tahmin edilmesinde kullanılabileceğini tespit etmiştir.

Altman (1968) çalışmasında, 66 üretim işletmesinin finansal oranlarını çoklu diskriminant analizi yöntemi ile incelemiş ve finansal başarısızlı̆ı̆n tahmin edilmesinde kullanılabilecek beş oranın oluşturduğu Z Skoru modelini geliştirmiştir. Z Skoru modeli:

$\mathrm{Z}=0.012 \mathrm{X}_{1}+0.014 \mathrm{X}_{2}+0.033 \mathrm{X}_{3}+0.006 \mathrm{X}_{4}+0.999 \mathrm{X}_{5}$

$\mathrm{X}_{1}$ : Çalışma sermayesi / Toplam varlıklar

$\mathrm{X}_{2}$ : Dağıtılmamış karlar / Toplam Varlıklar

$\mathrm{X}_{3}$ : FVÖK / Toplam varliklar

$\mathrm{X}_{4}$ : Özkaynaklar / Toplam borcun defter değeri

$\mathrm{X}_{5}$ : Satışlar/Toplam varlıklar.

Altman, Z Skoru 2,99'dan büyük olan işletmeleri "güvenli bölgede" (Non-Bankupt) sınıflandırmıştır. Bu bölgede yer alan işletmeler için finansal başarısızlık riski söz konusu değildir. Z Skoru 1,81 ile 2,99 arasında yer alan işletmeler "gri bölge"(gray area) içerisinde sınıflandırılmıştır. Bu bölgede yer alan işletmeler için finansal başarısızlık riski çok yüksek olmasa da yatırım yaparken ihtiyatlı davranılmalıdır. Z Skoru 1,81'in altında olan işletmeler ise finansal başarısızlık riski yüksek olan işletmeler olarak belirlenmiştir. Altman'ın bu çalışması finansal başarısızlı̆ın tahmininde bir yıl öncesi için \%95, iki yıl öncesi için ise \%72 oranında başarılı bir sınıflandırma performansı göstermiştir.

Deakin (1972) yaptığı çalışmada, Altman'ın Z Skoru modeli ile Beaver'in 1966 yılında geliştirdiği tekli diskriminant modelinin sınıflandırma başarılarını kıyaslamıştır. 
Çalışma sonucunda Beaver'in geliştirdiği modelin tek oran bazında Z Skorundan daha iyi bir sınıflandırma başarısı gösterdiğini tespit etmiştir.

Hill ve Perry (1996) yaptıkları çalışmada, NYSE ve AMEX'te işlem gören işletmeler üzerine yaptıkları çalışmada finansal açıdan başarısız olan işletmelerin likidite oranlarının daha düşük olduğunu ve bununla birlikte faiz ve işsizlik oranlarının finansal başarısızlık üzerinde etkili olduğunu tespit etmişlerdir.

İçerli ve Akkaya (2006) yaptıkları çalışmada, İstanbul Menkul Kıymetler Borsası'nda 1990-2003 arası dönemde işlem gören 40'1 başarısız ve 40'^ başarısız olmayan, toplam 80 üretim işletmesinin finansal tablolarından üretilen 10 adet finansal oranı $Z$ testi yöntemi ile incelemişlerdir. Sonuç olarak iki grubun finansal oranları arasında anlamlı bir farklılık olmadığını, finansal başarısızlığın büyük oranda yönetim hatalarından kaynaklandığını ortaya koymuşlardır.

Lin (2009) yaptığı çalışmada, 20 finansal oran kullanarak çoklu diskriminant, logit, probit ve yapay sinir ağları tekniklerinin finansal başarısızlığın ölçülmesindeki sınıflandırma başarılarını kıyaslamış ve logit yönteminin daha iyi bir sınıflandırma başarısı gösterdiğini tespit etmiştir.

Çelik (2010) yaptığı çalışmada finansal başarısızlığın ölçümlenmesinde diskriminant analizi ve yapay sinir ağları analizi yöntemlerini karşılaşıırmışıır. 36 özel sermayeli bankanın finansal oranları bu iki yöntemle incelenmiş ve finansal başarısızlıktan bir yıl öncesi için yapay sinir ağları, iki yıl öncesi için diskriminant analizi yönteminin daha başarılı bir sınıflandırma performansı gösterdiğini tespit etmiştir.

Terzi, (2011) çalı̧̧masında, gıda sektöründe faaliyet gösteren 22 işletmenin finansal tablolarından elde edilen 19 finansal oranı diskriminant analizi yöntemi ile incelemiştir. Gıda sektöründe faaliyet gösteren işletmeler için finansal başarısızlığın ölçümlenmesinde 6 adet oranın finansal açıdan başarısız olan işletmeler ile finansal açıdan başarısız olmayan işletmeler arasında anlamlı bir farklılık gösterdiğini tespit etmiştir.

Altunöz, (2013) çalışmasında bankaların finansal başarısızlık riskini ölçmede yapay sinir ağları yöntemini kullanmıştır. Toplam 36 adet özel sermayeli bankanın 36 finansal oranı üzerinde yapılan çalışmada finansal başarısızlıktan bir ve iki yıl öncesi için bir tahmin modeli geliştirilmiş̧ir. Söz konusu model finansal başarısızlıktan bir yıl öncesi için \%88, iki yıl öncesi için \%77 sınıflandırma başarısı göstermiştir.

\section{ISŞLETMELERDE BAŞARISIZLIK VE MALI BAŞARISIZLIĞA}

\section{GENEL BAKIŞ}

İşletmeler, topluma hizmet etmek, yaşamlarını sürdürmek ve kâr etmek amaçları gözetilerek kurulurlar. Ancak, finansal krizler, tüketici tercihlerine cevap verememe, teknolojik gelişmelerin gerisinde kalma ve doğal afetler gibi birçok etkenle baş etmek zorunda olan işletmeler zaman zaman finansal açıdan başarısızlı̆a düşebilmektedir. 
Bir işletmenin finansal açıdan başarısız olduğuna kanaat getirebilmek için pek çok farklı gösterge vardır. Bu göstergelere örnek olarak aşağıdaki durumları gösterebiliriz. (Aktaş vd. 2003: 12)

- İflas etme,

- Sermayenin yarısının kaybedilmiş olması,

- İşletme varlıklarının \%10’unun kaybedilmiş olması,

- $\quad$ Üç yıl üst üste zarar beyan edilmiş olması,

- Borçları ödemede güçlük çekilmesi,

- $\quad$ Üretimin durdurulmas1,

- $\quad$ Borçların varlık toplamını aşması.

Muhasebenin "Kişilik Kavramı" gereği işletmeler sahipleri ve ortaklarından bağımsız olarak bir kişiliğe sahiptir. İşletmeler tüzel kişilikleri ile tanınır. Dolayısı ile işletmelerde ortaya çıkan başarısızlık, tüzel bir kişilik olan işletmenin başarısızlığı olarak değerlendirilmektedir.

İşletmelerde başarısızlık konusu iki ana başlık altında toplanır. Bunlar;

- $\quad$ Ekonomik başarısızlık (işletmenin kâr elde edememesi) ve

- $\quad$ Finansal başarısızlık (borçların ödenmesi konusunda sıkıntıya düşülmesi).

\subsection{Ekonomik Başarısızlık}

Ekonomik başarısızlık, işletmelerin gelirlerinin işletme maliyetlerini karşılayamaması olarak tanımlanabilir.(Uzun, 2005: 159) Bu tanıma göre, gelirleri maliyetlerinden yüksek olan işletmeler de ekonomik açıdan başarılı olarak nitelendirilir. Ekonomik başarısızlık atıl işletme kapasitesi, hatalı fiyatlandırma politikaları, etkin olamayan nakit yönetimi, esas faaliyet alanı dışındaki başarısız girişimler gibi birçok etkene bağlı olarak ortaya çıkabilir.

\subsection{Finansal Başarısızlık}

İngilizcede "Business failure" olarak adlandırılan finansal başarısızlık en geniş anlamda; işletmenin finansal yükümlülüklerini yerine getirirken zorluk çekmesi ya da hiç yerine getirememesi olarak tanımlanmaktadır. (İçerli ve Akkaya, 2006: 414) İşletmenin borç ödeme sıkıntısı çekmesi teknik başarısızlık olarak ifade edilirken, işletme borçlarını ödemede varlıkların yetersiz kalması durumu iflas olarak ifade edilir.(Akkaya ve Tükenmez, 2013: 182)

Gelişmiş ülkelerde yapılan araştırmalarda finansal başarısızlık kriteri olarak genellikle iflas benimsenirken, gelişmekte olan ülkelerde iflas etmiş işletme sayısının az olmasından dolayı daha esnek bir finansal başarısızlık tanımı kullanılmaktadır. $\mathrm{Bu}$ tanıma göre işletmelerin vadesi gelen borçlarını ödemede sıkıntı yaşaması ile iflas etmesi arasındaki tüm durumlar finansal başarısızlık olarak ifade edilir. Zira finansal başarısızlığın son aşaması olan 
iflas gerçekleştiğinde işletme finansal başarısızlık risklerine zaten maruz kalmış olduğundan finansal başarısızlık öngörülmesi gereken bir olgu olmaktan çıkar. (Özdemir vd., 2012: 25)

\subsection{1. İşletmelerde Finansal Başarısızlığa Neden Olan Etkenler}

İşletmeler arası rekabetin oldukça yüksek seviyelere ulaştığı günümüzde, bazı işletmeler sert koşullara uyum gösteremeyip başarısızlığa uğramaktadır. Bu başarısızlıklar işletmelerin kendi içindeki aksaklıklardan kaynaklı olabileceği gibi işletmeden bağımsız olarak gelişen birtakım dış etkenlerden de kaynaklanıyor olabilir. Bu bağlamda finansal başarısızlığa neden olan faktörler iki ana başlık altında incelenebilir

- $\quad$ İşletme içi (içsel) finansal başarısızlık nedenleri,

- İşletme dış1 (dışsal-çevresel) finansal başarısızlık nedenleri.

\subsubsection{1. İşletme İçi (İçsel) fFnansal Başarısızlık Nedenleri}

İşletme içi finansal başarısızlık nedenleri, işletmenin faaliyetleri ile ilgili olarak gelişen; işletme tarafından kontrol edebilecek nitelikteki nedenlerdir. Bu içsel başarısızlık nedenlerini genel anlamda üç ana başlık altında toplayabiliriz. Bunlar:

- İşletme sermayesi yetersizliği,

- $\quad$ Aşırı derecede borçlanma,

- Yönetim hataları şeklinde sıralanabilir.

Duran varlıkların nakde dönüştürülmesinin uzun süreler gerektirebileceği göz önünde bulundurulursa, kısa vadeli borç ödeme gücünün arttırılmasında, çalışma sermayesinin güçlendirilmesinin önemi oldukça yüksektir. Ancak, çalışma sermayesinin özkaynak ya da uzun vadeli yabancı kaynak kullanılarak arttırılması gerekir. Finansal başarısızlığa uğrayan bir işletmenin çalışma sermayesini kısa vadeli yabancı kaynaklarla arttırmaya çalışmak spekülatif bir çözüm olabilir. Zira bu finansman türü işletmenin borçlarının vadesini bir dönemden fazla erteleyememekle birlikte işletmeye finansman maliyeti de doğuracaktır.

İşletmelerin aşırı derecede borçlanma kaynaklı başarısızlı̆ga düşmemeleri için yapılması gereken, işletmenin gelecekteki yükümlülüklerini karşılama gücüne sahip olup olmadığını belirlemektir. Bu da oran analizi ve nakit akış analizi ile yapılabilir. Bu analizler ve diğer bilgilerle birlikte işletme için en uygun borçlanma yapısı belirlenmeli ve aşırı borçlanmadan kaçınılmalıdır. (Karacan ve Savc1, 2011: 45)

İşletmelerin finansal başarısızlı̆̆a uğramalarına neden olan en büyük iç faktörlerden bir diğeri yönetim hatalarıdır. Yönetim hataları aynı zamanda sermaye yönetimi ve borçlanma kararları gibi faktörleri de etkilediği için önemi daha artmaktadır. İşletme yönetiminin sermaye yönetimi, alacak tahsil politikası, stok yönetimi, yatırım kararları, kar dağıtım politikası gibi konularda vereceği yanlış kararlar finansal başarısızlığa kapı aralamaktadır.

\subsubsection{2. İşletme Dışı (Dışsal - Çevresel) Finansal Başarısızlık Nedenleri}

İşletmelerin kârlılığını ve yaşamını devam ettirebilmesi konusunda dış çevrenin hayati bir önemi vardır. İşletme yöneticileri, işletmenin içinde bulunduğu çevreyi büyük bir 
hassasiyetle analiz etmeli ve stratejilerini bu doğrultuda geliştirmelidir. Ancak işletmenin kontrolü dışında gelişen ve birbirinden bağımsız olarak işletmeyi farklı şekillerde etkileyen birçok çevresel faktörden söz edilebilir. Ancak temel bir gruplandırma yapıldığında işletme dışı başarısızlık nedenleri beş ana başlık altında incelenebilir. Bunlar:

- Makroekonomik etkenler,

- $\quad$ Siyasi ve hukuki etkenler,

- $\quad$ Sosyal etkenler,

- $\quad$ Pazarın yapısı,

- $\quad$ Doğal etkenler şeklinde siralanır.

Ülke ekonomisindeki makro değişiklikler işletmelerde büyük etkiler yaratabilir. Örneğin, konjonktürel dalgalanmalar kredi politikalarını ve fiyat düzeylerini etkilerken enflasyonu aşan faiz uygulamaları kredi maliyetlerini arttırabilir. Makroekonomik değişkenlere müdahale etmek işletmelerin ellerinde olan bir durum olmadığ 1 için, işletme yöneticileri bu dönemlerde zararın önüne geçebilmek ya da minimum seviyeye indirebilmek için ellerindeki fonları daha verimli ve etkin kullanmalıdır. (Usta, 2005: 6-7)

İşletmeler, faaliyet gösterdikleri ülkelerin hukuki konjonktürüne uymak zorundadır. Kuruluş faaliyetleri, borç ve alacak ilişkileri, personel, yöneticiler, tüketiciler ve devlet ile olan ilişkiler yasalar ile sınırlanmıştır ve işletmeler bu yasal düzenlemelere göre hareket etmekle mükelleftir. Aksi durumda işletmeler cezai yaptırımlara maruz kalabilir ve bu durum da prestij kaybına yol açabilir. (Büker vd., 1997: 524)

İşletmeler tüzel kişilikleri ile faaliyetlerini sürdürdüğü toplumun bir parçasıdır. İşletmeleri doğrudan etkileyen diğer dış etkenler gibi sosyal etkenler de işletmeler tarafindan kontrol edilemez. Ancak işletmenin temas halinde bulunduğu toplumun gerekliliklerini kestirmesi mümkündür. Örneğin, fazla üretim yapmak stok maliyetlerini yükseltecek, eksik üretim yapmak ise birim maliyetleri yükseltecektir. Her iki durum da işletmeye ek maliyet çıkarıp işletmenin karlılığını düşürücü etkiye sahiptir. İşletmeler, toplumun ihtiyaçlarını ve tercihlerini göz önünde bulundurarak geleceğe yönelik talep tahminlerini hazırlayabilirler. (Usta, 2005: 68-69)

Pazarın yapısından kaynaklanan başarısızlık nedenleri her ne kadar dişsal başarısızlık nedenleri arasında yer alıyor olsa da işletmenin faaliyet gösterdiği pazarı etkin bir şekilde analiz edip tanıması ile bu nedenlerin işletme üzerindeki etkileri en aza indirilebilir. İşletmelerin kredili satış ve finansman politikalarını faaliyet gösterdikleri pazarın gereksinimlerine göre belirlemeleri finansal başarısızlık riskini azaltabilir.

Doğal etkenler, işletmenin faaliyetini sürdürmesine engel teşkil edebilecek deprem, su basması, heyelan gibi işletmenin kontrolü dışında gelişen olayları kapsar. Bu etkenler, işletmenin üretim ya da dağıtım yapmasını etkileyeceği gibi işletmenin hammadde ve ara ürünlere ulaşmasına da engel olabilir. Doğal etkenler tahmin edilmesi mümkün olmadığ için diğer finansal başarısızlık nedenlerinden ayrılırlar. İşletmeler ülkeler arası ilişkileri, finansal 
piyasaları, rakip işletmeleri ve tüketicileri iyi analiz ederek diğer finansal başarısızlık nedenleri ile ilgili tahminler geliştirebilirler. Ancak doğal etkenlerin tahmin edilmesinin mümkün olmayışı, işletmeleri bu konuda çaresiz kılmaktadır.

\subsection{Finansal Başarısızlık ve Finansal Kriz İlişkisi}

Finansal krizler de işletmelerde başarısızlık riskini ortaya çıkaran nedenlerden biridir. Finansal krizler esnasında piyasada likidite sıkışıklı̆̆ ortaya çıkar ve bu nedenle tüm ekonomiyi etkileyecek bir kriz yayılması söz konusu olur. Finansal kurum ve kuruluşlar ellerindeki likiditeyi daha temkinli kullanmak isteyecekler ve fon sağlama konusunda daha tutucu davranacaklardır. Bunun sonucunda piyasada oluşan kredi azlığı nedeniyle ekonomide harcamalar kısılacak ve bu durum, reel sektör kesiminin daha az gelir elde etmesi ile sonuçlanacaktır. Bununla birlikte, elinde fon fazlası olan birimler, bireyler, şirketler vs., fon fazlalarını talep eden taraflardan daha yüksek getiri, faiz talep edeceklerdir. Piyasada faizlerin yükselmesi ile birlikte tasarruf eğilimi artacak ve harcama eğilimi azalacaktır. Bu da yine ekonominin yavaşlamasına ve hatta daralmasina yol açacaktır.

Ekonomik kriz dönemlerinde başarılı yönetime sahip olan firmalar, kriz durumunu firsata çevirme şansına sahiptirler. Krizin firsata çevrilebilmesi için öncelikle işletmenin sermaye yapısının buna izin vermesi gerekmektedir. Yeterli likidite ve dengeli varlık - kaynak yapılandırması sayesinde işletmeler bu şansa sahip olabileceklerdir. Ekonomik kriz dönemlerinde işletmeler avantaja tedarik zincirinde yer alan tedarikçileri ile yeni anlaşma yapma, önemli oralarda indirim alabilme ya da esnek ödeme koşulları gibi avantajlar elde ederek maliyetlerini azaltma yönünde önlem alabilirler. Ekonominin bir bütün olarak hızının yavaşladığı bir dönemde pazarlama ve reklam faaliyetlerinde de piyasada meydana gelen durgunluk avantaja çevrilmek için kullanılabilir. Reklam mecraları ekonomik kriz dönemlerinde daha ucuza hizmet vermek durumunda kalırlar çünkü talep eskiye nazaran daha azdır. Ekonomiyi canlandırmak için hükümetler tarafindan da çeşitli vergi avantajları ve teşvik paketleri de piyasaya sunulmaktadır. Yeterli kaynağa sahip işletmeler yatırım yapma maliyetlerinin düştüğü, vergi ve teşvik avantajlarının olduğu bu gibi durumları firsata çevirebilirler. Ancak unutulmaması gereken nokta ise krizin ne kadar süreceğinin belirli olmamasıdır. Dolayısıyla sermaye yapısı ne kadar güçlü de olsa işletmeler yatırım ve harcamaların büyük bir dikkatle yönetmelidirler.

4. HISSSELERİ BISST'TE IŞLEM GÖREN DOKUMA, GIYIM EŞYASI VE DERİ SEKTÖRÜ IŞLETMELERI ÜZERINE BIIR UYGULAMA

\subsection{Araştırmanın Amacı}

$\mathrm{Bu}$ çalışmanın amacı, ülke ekonomisinde büyük yeri olan dokuma, giyim eşyası ve deri sektöründe faaliyet gösteren işletmelerin finansal başarısızlığa uğrama riskini ölçmede kullanılabilecek finansal oranları saptamaktır. 


\subsection{Araştırmanın Sınırları}

$\mathrm{Bu}$ çalışma yalnızca hisseleri BİST’te işlem gören dokuma, giyim eşyası ve deri faaliyet kolundaki işletmeleri kapsamaktadır. Söz konusu faaliyet kolunda halihazırda 27 işletme bulunmasına rağmen, bu işletmelerden Arbul Entegre Tekstil İşletmeleri A.Ş. 2014 yılı başında BİST'e kote olduğundan ve Gimsan Gediz İplik ve Mensucat Sanayi A.Ş. faaliyetlerinin 2010 yılında durdurulduğundan dolayı çalışmaya toplam 25 işletme dahil edilmiştir.

\subsection{Analizde Kullanılan Değişkenler}

Çalışmanın bağımsız değişkenlerini BİST’e kote dokuma, giyim eşyası ve deri sektörü işletmelerinin finansal oranları oluşturmaktadır. $\mathrm{Bu}$ çalışmada ilgili şirketlerin likidite, finansal yapı, faaliyet devir hızı ve kârlılık oran gruplarından toplam 23 oran hesaplanmıştır. Bağımlı değişkenler ise, söz konusu işletmelerin finansal açıdan başarısız olup olmadığıdır. Analizde kullanılan finansal oranlar Tablo 1'de verilmiştir.

Tablo 1. Analizde kullanılan finansal oranlar ve formülleri

\begin{tabular}{|c|c|c|}
\hline $\begin{array}{l}\text { Oran } \\
\text { Grubu }\end{array}$ & Oran Adı & Hesaplanışı \\
\hline \multirow{3}{*}{ 窇 } & Cari oran & Dönen varlıklar / Kısa vadeli yabancı kaynaklar \\
\hline & Likit (Asit-test) oran & (Dönen varlıklar-Stoklar) / Kısa vadeli yabancı kaynaklar \\
\hline & Nakit oran & $\begin{array}{l}\text { (Dönen varlıklar-Stoklar-Alacaklar)/ Kisa vadeli yabancı } \\
\text { kaynaklar }\end{array}$ \\
\hline \multirow{4}{*}{ 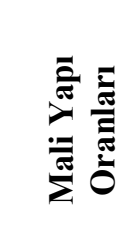 } & Toplam Borç/Özkaynak & Yabancı kaynaklar / Özkaynaklar \\
\hline & Kvb/Toplam borç & Kısa vadeli yabancı kaynaklar / Yabancı kaynaklar \\
\hline & Duran varlıklar/Özkaynaklar & Duran varlıklar / Özkaynaklar \\
\hline & Faiz karşılama oranı & FVÖK / Faiz giderleri \\
\hline \multirow{10}{*}{ 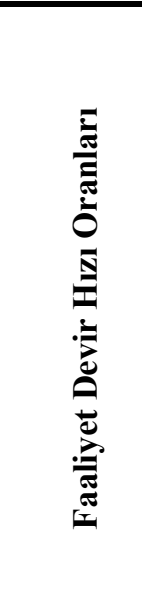 } & Alacak devir hizı & Net satışlar / Ticari alacaklar \\
\hline & Ortalama tahsilat süresi & 360 / Alacak devir hızı \\
\hline & Stok devir hızı & Satışların maliyeti / Ortalama stok tutarı \\
\hline & Ortalama stokta kalma süresi & 360 / Stok devir hızı \\
\hline & Ticari borç devir hızı & Satışların maliyeti / Ticari borçlar \\
\hline & Aktif devir hızı & Net satışlar / Aktif toplamı \\
\hline & Özkaynak devir hızı & Net satışlar / Özkaynaklar \\
\hline & Mdv devir hizı & Net satışlar / Maddi duran varlıklar \\
\hline & Dönen varlık devir hızı & Net satışlar / Dönen varlıklar \\
\hline & Ortalama etkinlik süresi & Ortalama tahsilat süresi + Ortalama stokta kalma süresi \\
\hline \multirow{3}{*}{ 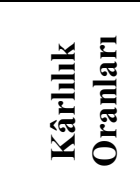 } & Brüt kâr marji & Brüt satış kârı / Net satışlar \\
\hline & Faaliyet kâr marjı & Faaliyet kârı / Net satışlar \\
\hline & Net kâr marji & Net kâr / Net satışlar \\
\hline
\end{tabular}




\begin{tabular}{|l|l|}
\hline Özkaynak kârlılı̆̆ı & Net kâr / Özkaynaklar \\
\hline Aktif kârlılığı & Net kâr / Aktif Toplamı \\
\hline Fvök/Aktif & Faiz ve vergi öncesi kâr / Aktif toplamı \\
\hline
\end{tabular}

\subsection{Yöntem}

$\mathrm{Bu}$ çalışmada işletmelerin finansal tabloları KAP internet sitesinden alınmış ve söz konusu tablolara oran analizi yapılarak analiz için gerekli veriler oluşturulmuştur.

İşletmelerin finansal başarısızlık kriteri olarak Altman Z Skoru ve ilgili yıl kâr/zarar durumları benimsenmiştir. Bu bağlamda Altman Z Skoru 1,81'in altında olan ve/veya ilgili yılda zarar beyan etmiş olan işletmeler finansal açıdan başarısız olarak sınıflandırılmıştır. Buna paralel olarak, Z Skoru 1,81 ve üzerinde olan ve ilgili yılda zarar beyan etmemiş olan işletmeler ise başarısız olmayan işletmeler olarak sınıflandırılmıştır. Bu ayrıştırma sonucunda 14 işletme başarısız, 11 işletme ise başarısız olmayan işletmeler olarak sınıflandırılmıştır.

Alanyazın incelendiğinde finansal başarısızlığın tahmin edilmesine yönelik çalışmalarda diskriminant analizinin sıklıkla kullanıldığı görülmektedir. $\mathrm{Bu}$ yöntem uygulanırken öncelikle analize dahil edilecek işletmeler finansal açıdan başarısız olan ve finansal açıdan başarısız olmayan işletmeler olmak üzere iki öncü gruba ayrılır. Söz konusu ayrıştırma işlemi benimsenmiş olan finansal başarısızlık kriteri baz alınarak yapılır. Analizde kullanılacak olan finansal oranlar hesaplanır. İşletmelerin finansal başarısızlık durumu grup (bağımlı) değişkenleri, finansal oranları ise test (bağımsız) değişkenleri oluşturur. Diskriminant analizi sonucunda belirlenen anlamlılık düzeyinde (\%1,\%5,\%10 gibi) gruplar arasında farklılık gösteren finansal oranlar belirlenir. Diskriminant analizinin sinıflandırma fonksiyonundan yararlanılarak modelin doğru sınıflandırma başarısı ölçülebilir.

Bu çalışmada BİST'de faaliyet gösteren 25 adet Dokuma, Giyim Eşyası ve Deri işletmesi Altman Z Skoru ve ilgili yıl kâr/zarar durumlarına göre öncü gruplara atanmıştır. Bu ayrıştırma sonucunda 14 işletme finansal açıdan başarısız işletmeler öncü grubuna, 11 işletme ise finansal açıdan başarısız olmayan işletmeler öncü grubuna atanmıştır. Tüm işletmelerin finansal oranları ayrı ayrı hesaplanmış ve öncelikle tek örneklem Kolmogorow-Smirnow testi ile verilerin normal dağılım gösterip göstermediği incelenmiştir. Tek örneklem KolmogorowSmirnow Testi sonuçları Tablo 2'de verilmiştir.

Tablo 2. Normal dağılıma ilişkin tek örneklem Kolmogorow-Smirnow Testi sonuçları

\begin{tabular}{|l|l|l|l|l|}
\hline \multicolumn{4}{|c|}{ Normal Dağılım Tablosu } \\
\hline & $\mathbf{H}_{\mathbf{0}}$ Hipotezi & Test & Anlamlılık & Karar \\
\hline $\mathbf{1}$ & $\begin{array}{l}\text { Cari oran 2,100 ortalama ve 1,89 } \\
\text { standart sapma ile normal dağılım } \\
\text { göstermektedir. }\end{array}$ & $\begin{array}{l}\text { One-Sample } \\
\text { Kolmogorov- } \\
\text { Smirnov Test }\end{array}$ & $\mathrm{P}<0,05$ & $\mathbf{H}_{\mathbf{0}}$ Ret \\
\hline $\mathbf{2}$ & $\begin{array}{l}\text { Likit oran 1,453 ortalama ve 1,71 } \\
\text { standart sapma ile normal dağılım }\end{array}$ & $\begin{array}{l}\text { One-Sample } \\
\text { Kolmogorov- }\end{array}$ & $\mathrm{P}>0,05$ & $\mathrm{H}_{0}$ Kabul \\
\hline
\end{tabular}




\begin{tabular}{|c|c|c|c|c|}
\hline & göstermektedir. & Smirnov Test & & \\
\hline 3 & $\begin{array}{l}\text { Nakit oran } 0,595 \text { ortalama ve } 1,21 \\
\text { standart sapma ile normal dağgllım } \\
\text { göstermektedir. }\end{array}$ & $\begin{array}{l}\text { One-Sample } \\
\text { Kolmogorov- } \\
\text { Smirnov Test }\end{array}$ & $\mathrm{P}<0,05$ & $\mathbf{H}_{0}$ Ret \\
\hline 4 & $\begin{array}{l}\text { Borç/özkaynak } 1,218 \text { ortalama ve } \\
0,87 \text { standart sapma ile normal } \\
\text { dağılım göstermektedir. }\end{array}$ & $\begin{array}{l}\text { One-Sample } \\
\text { Kolmogorov- } \\
\text { Smirnov Test }\end{array}$ & $\mathrm{P}>0,05$ & $\mathrm{H}_{0}$ Kabul \\
\hline 5 & $\begin{array}{l}\text { KVB/toplam borç } 0,686 \text { ortalama ve } \\
0,24 \text { standart sapma ile normal } \\
\text { dağ } 1 \text { llm göstermektedir. }\end{array}$ & $\begin{array}{l}\text { One-Sample } \\
\text { Kolmogorov- } \\
\text { Smirnov Test }\end{array}$ & $\mathrm{P}>0,05$ & $\mathrm{H}_{0}$ Kabul \\
\hline 6 & $\begin{array}{l}\text { Dur.varlık/ozkaynak } 1,108 \text { ortalama } \\
\text { ve } 0,64 \text { standart sapma ile normal } \\
\text { dağ } 1 \text { lım göstermektedir. }\end{array}$ & $\begin{array}{l}\text { One-Sample } \\
\text { Kolmogorov- } \\
\text { Smirnov Test }\end{array}$ & $\mathrm{P}>0,05$ & $\mathrm{H}_{0}$ Kabul \\
\hline 7 & $\begin{array}{l}\text { Faiz karş1lama oran } 11,477 \text { ortalama } \\
\text { ve } 60,27 \text { standart sapma ile normal } \\
\text { dağ } 1 \text { lım göstermektedir. }\end{array}$ & $\begin{array}{l}\text { One-Sample } \\
\text { Kolmogorov- } \\
\text { Smirnov Test }\end{array}$ & $\mathrm{P}<0,05$ & $\mathbf{H}_{0}$ Ret \\
\hline 8 & $\begin{array}{l}\text { Alacak devir hız1 } 4,722 \text { ortalama ve } \\
3,46 \text { standart sapma ile normal } \\
\text { dağılım göstermektedir. }\end{array}$ & $\begin{array}{l}\text { One-Sample } \\
\text { Kolmogorov- } \\
\text { Smirnov Test }\end{array}$ & $\mathrm{P}>0,05$ & $\mathrm{H}_{0}$ Kabul \\
\hline 9 & $\begin{array}{l}\text { Ort. tahsilat süresi } 192,823 \text { ortalama } \\
\text { ve } 470,03 \text { standart sapma ile normal } \\
\text { dağılım göstermektedir. }\end{array}$ & $\begin{array}{l}\text { One-Sample } \\
\text { Kolmogorov- } \\
\text { Smirnov Test }\end{array}$ & $\mathrm{P}<0,05$ & $\mathbf{H}_{0}$ Ret \\
\hline 10 & $\begin{array}{l}\text { Stok devir hız1 4,631 ortalama ve } \\
\text { 4,56standart sapma ile normal } \\
\text { dağılım göstermektedir. }\end{array}$ & $\begin{array}{l}\text { One-Sample } \\
\text { Kolmogorov- } \\
\text { Smirnov Test }\end{array}$ & $\mathrm{P}<0,05$ & $\mathbf{H}_{0}$ Ret \\
\hline 11 & $\begin{array}{l}\text { Ort. stokta kalma süresi } 173,921 \\
\text { ortalama ve } 272,56 \text { standart sapma } \\
\text { ile normal dağılım göstermektedir. }\end{array}$ & $\begin{array}{l}\text { One-Sample } \\
\text { Kolmogorov- } \\
\text { Smirnov Test }\end{array}$ & $\mathrm{P}<0,05$ & $\mathbf{H}_{0}$ Ret \\
\hline 12 & $\begin{array}{l}\text { Tic. borç devir hızı } 8,266 \text { ortalama ve } \\
12,26 \text { standart sapma ile normal } \\
\text { dağılım göstermektedir. }\end{array}$ & $\begin{array}{l}\text { One-Sample } \\
\text { Kolmogorov- } \\
\text { Smirnov Test }\end{array}$ & $\mathrm{P}<0,05$ & $\mathbf{H}_{0}$ Ret \\
\hline 13 & $\begin{array}{l}\text { Aktif devir hızı } 0,658 \text { ortalama ve } \\
0,34 \text { standart sapma ile normal } \\
\text { dağılım göstermektedir. }\end{array}$ & $\begin{array}{l}\text { One-Sample } \\
\text { Kolmogorov- } \\
\text { Smirnov Test }\end{array}$ & $\mathrm{P}>0,05$ & $\mathrm{H}_{0}$ Kabul \\
\hline 14 & $\begin{array}{l}\text { Özkaynak devir hızı } 1,564 \text { ortalama } \\
\text { ve } 1,32 \text { standart sapma ile normal } \\
\text { dağılım göstermektedir. }\end{array}$ & $\begin{array}{l}\text { One-Sample } \\
\text { Kolmogorov- } \\
\text { Smirnov Test }\end{array}$ & $\mathrm{P}>0,05$ & $\mathrm{H}_{0}$ Kabul \\
\hline 15 & $\begin{array}{l}\text { MDV devir hızı } 3,184 \text { ortalama ve } \\
3,03 \text { standart sapma ile normal } \\
\text { dağllım göstermektedir. }\end{array}$ & $\begin{array}{l}\text { One-Sample } \\
\text { Kolmogorov- } \\
\text { Smirnov Test }\end{array}$ & $\mathrm{P}>0,05$ & $\mathrm{H}_{0}$ Kabul \\
\hline 16 & $\begin{array}{l}\text { Dönen varlık devir hızı } 1,376 \\
\text { ortalama ve } 0,61 \text { standart sapma ile } \\
\text { normal dağılım göstermektedir. }\end{array}$ & $\begin{array}{l}\text { One-Sample } \\
\text { Kolmogorov- } \\
\text { Smirnov Test }\end{array}$ & $\mathrm{P}>0,05$ & $\mathrm{H}_{0}$ Kabul \\
\hline 17 & $\begin{array}{l}\text { Ort. etkinlik süresi } 366,742 \text { ortalama } \\
\text { ve } 733,31 \text { standart sapma ile normal } \\
\text { dağ } 1 \text { llı göstermektedir. }\end{array}$ & $\begin{array}{l}\text { One-Sample } \\
\text { Kolmogorov- } \\
\text { Smirnov Test }\end{array}$ & $\mathrm{P}<0,05$ & $\mathbf{H}_{0}$ Ret \\
\hline 18 & $\begin{array}{l}\text { Brüt kâr marj1 } 0,210 \text { ortalama ve } \\
0,12 \text { standart sapma ile normal } \\
\text { dağılım göstermektedir. }\end{array}$ & $\begin{array}{l}\text { One-Sample } \\
\text { Kolmogorov- } \\
\text { Smirnov Test }\end{array}$ & $\mathrm{P}>0,05$ & $\mathrm{H}_{0} \mathrm{Kabul}$ \\
\hline 19 & $\begin{array}{l}\text { Faaliyet kâr marj1 }-0,218 \text { ortalama ve } \\
1,15 \text { standart sapma ile normal }\end{array}$ & $\begin{array}{l}\text { One-Sample } \\
\text { Kolmogorov- }\end{array}$ & $\mathrm{P}<0,05$ & $\mathbf{H}_{0}$ Ret \\
\hline
\end{tabular}




\begin{tabular}{|c|c|c|c|c|}
\hline & dağ1lım göstermektedir. & Smirnov Test & & \\
\hline 20 & $\begin{array}{l}\text { Net kâr marj1 }-0,384 \text { ortalama ve } \\
1,64 \text { standart sapma ile normal } \\
\text { dağlım göstermektedir. }\end{array}$ & $\begin{array}{l}\text { One-Sample } \\
\text { Kolmogorov- } \\
\text { Smirnov Test }\end{array}$ & $\mathrm{P}<0,05$ & $\mathrm{H}_{0}$ Ret \\
\hline 21 & $\begin{array}{l}\text { Özkaynak karlılı̆̆ }-0,068 \text { ortalama } \\
\text { ve } 0,18 \text { standart sapma ile normal } \\
\text { dağılım göstermektedir. }\end{array}$ & $\begin{array}{l}\text { One-Sample } \\
\text { Kolmogorov- } \\
\text { Smirnov Test }\end{array}$ & $\mathrm{P}>0,05$ & $\mathrm{H}_{0}$ Kabul \\
\hline 22 & $\begin{array}{l}\text { Aktif karlılığ }-0,028 \text { ortalama ve } \\
0,08 \text { standart sapma ile normal } \\
\text { dağılım göstermektedir. }\end{array}$ & $\begin{array}{l}\text { One-Sample } \\
\text { Kolmogorov- } \\
\text { Smirnov Test }\end{array}$ & $\mathrm{P}>0,05$ & $\mathrm{H}_{0} \mathrm{Kabul}$ \\
\hline 23 & $\begin{array}{l}\text { FVÖK/aktif toplamı } 0,014 \text { ortalama } \\
\text { ve } 0,09 \text { standart sapma ile normal } \\
\text { dağılım göstermektedir. }\end{array}$ & $\begin{array}{l}\text { One-Sample } \\
\text { Kolmogorov- } \\
\text { Smirnov Test }\end{array}$ & $\mathrm{P}>0,05$ & $\mathrm{H}_{0}$ Kabul \\
\hline
\end{tabular}

Görüldügü üzere; cari oran, nakit oran, faiz karşılama oranı, ortalama tahsilat süresi, stok devir hızı, ortalama stokta kalma süresi, ticari borç devir hızı ve brüt kâr marjı oranlarında normal dağılım gözlenmediği tespit edilmiştir. Verilerde normal dağılım gözlenemediğinden dolayı, hangi finansal oranların gruplar arasında anlamlı farklılık gösterdiğinin belirlenmesinde parametrik olmayan bir istatistiki test olan Bağımsız Örneklemler İçin Mann-Whitney U Testi kullanılmıştır. Bağımsız örneklemler için MannWhitney U testi sonuçlarına Tablo 3'te yer verilmiştir.

Tablo 3. Bağımsız örneklemler için Mann-Whitney U testi sonuçları

\begin{tabular}{|c|c|c|c|c|}
\hline \multicolumn{5}{|c|}{ Hipotez Testi Özeti } \\
\hline & $\mathbf{H}_{0}$ Hipotezi & Test & Anlamlılık & Karar \\
\hline 1 & $\begin{array}{l}\text { Cari oran dağılımı gruplar } \\
\text { arasında farklılık } \\
\text { göstermemektedir. }\end{array}$ & $\begin{array}{l}\text { Independent- } \\
\text { Samples Mann- } \\
\text { Whitney U Test }\end{array}$ & $\mathrm{P}>0,05$ & $\mathrm{H}_{0} \mathrm{Kabul}$ \\
\hline 2 & $\begin{array}{l}\text { Likit oran dağılımı gruplar } \\
\text { arasında farklılık } \\
\text { göstermemektedir. }\end{array}$ & $\begin{array}{l}\text { Independent- } \\
\text { Samples Mann- } \\
\text { Whitney U Test }\end{array}$ & $\mathrm{P}>0,05$ & $\mathrm{H}_{0}$ Kabul \\
\hline 3 & $\begin{array}{l}\text { Nakit oran dağılımı gruplar } \\
\text { arasında farkl1lık } \\
\text { göstermemektedir }\end{array}$ & $\begin{array}{l}\text { Independent- } \\
\text { Samples Mann- } \\
\text { Whitney U Test }\end{array}$ & $\mathrm{P}>0,05$ & $\mathrm{H}_{0}$ Kabul \\
\hline 4 & $\begin{array}{l}\text { Borç/özkaynak dağılımı gruplar } \\
\text { arasında farklılık } \\
\text { göstermemektedir. }\end{array}$ & $\begin{array}{l}\text { Independent- } \\
\text { Samples Mann- } \\
\text { Whitney U Test }\end{array}$ & $\mathrm{P}>0,05$ & $\mathrm{H}_{0}$ Kabul \\
\hline 5 & $\begin{array}{l}\text { KVB/toplam borç dağ } 11 \text { lıı } \\
\text { gruplar arasında farklılık } \\
\text { göstermemektedir. }\end{array}$ & $\begin{array}{l}\text { Independent- } \\
\text { Samples Mann- } \\
\text { Whitney U Test }\end{array}$ & $\mathrm{P}>0,05$ & $\mathrm{H}_{0}$ Kabul \\
\hline 6 & $\begin{array}{l}\text { Duran varlık/özkaynak dağılımı } \\
\text { gruplar arasında farklılık } \\
\text { göstermemektedir. }\end{array}$ & $\begin{array}{l}\text { Independent- } \\
\text { Samples Mann- } \\
\text { Whitney U Test }\end{array}$ & $\mathrm{P}<0,10$ & $\begin{array}{l}H_{0} \text { Ret } \\
(\alpha=0,10)\end{array}$ \\
\hline
\end{tabular}




\begin{tabular}{|c|c|c|c|c|}
\hline 7 & $\begin{array}{l}\text { Faiz karşılama oranı dağılımı } \\
\text { gruplar arasında farklılık } \\
\text { göstermemektedir. }\end{array}$ & $\begin{array}{l}\text { Independent- } \\
\text { Samples Mann- } \\
\text { Whitney U Test }\end{array}$ & $\mathrm{P}<0,05$ & Hot $_{0}$ Ret \\
\hline 8 & $\begin{array}{l}\text { Alacak devir hızı oranı dağılımı } \\
\text { gruplar arasında farklılık } \\
\text { göstermemektedir. }\end{array}$ & $\begin{array}{l}\text { Independent- } \\
\text { Samples Mann- } \\
\text { Whitney U Test }\end{array}$ & $\mathrm{P}>0,05$ & $\mathrm{H}_{0}$ Kabul \\
\hline 9 & $\begin{array}{l}\text { Ort. tahsilat süresi dağ } 111 \mathrm{~m} 1 \\
\text { gruplar arasında farkl1lık } \\
\text { göstermemektedir }\end{array}$ & $\begin{array}{l}\text { Independent- } \\
\text { Samples Mann- } \\
\text { Whitney U Test }\end{array}$ & $\mathrm{P}>0,05$ & $\mathrm{H}_{0}$ Kabul \\
\hline 10 & $\begin{array}{l}\text { Stok devir hızı dağılımı gruplar } \\
\text { arasında farklılık } \\
\text { göstermemektedir. }\end{array}$ & $\begin{array}{l}\text { Independent- } \\
\text { Samples Mann- } \\
\text { Whitney U Test }\end{array}$ & $\mathrm{P}>0,05$ & $\mathrm{H}_{0} \mathrm{Kabul}$ \\
\hline 11 & $\begin{array}{l}\text { Ort. stokta kalma süresi } \\
\text { dağılımı gruplar arasında } \\
\text { farklılık göstermemektedir. }\end{array}$ & $\begin{array}{l}\text { Independent- } \\
\text { Samples Mann- } \\
\text { Whitney U Test }\end{array}$ & $\mathrm{P}>0,05$ & $\mathrm{H}_{0} \mathrm{Kabul}$ \\
\hline 12 & $\begin{array}{l}\text { Tic. borç devir hızı dağılımı } \\
\text { gruplar arasında farklılık } \\
\text { göstermemektedir. }\end{array}$ & $\begin{array}{l}\text { Independent- } \\
\text { Samples Mann- } \\
\text { Whitney U Test }\end{array}$ & $\mathrm{P}>0,05$ & $\mathrm{H}_{0}$ Kabul \\
\hline 13 & $\begin{array}{l}\text { Aktif devir hızı dağılımı gruplar } \\
\text { arasında farklılık } \\
\text { göstermemektedir. }\end{array}$ & $\begin{array}{l}\text { Independent- } \\
\text { Samples Mann- } \\
\text { Whitney U Test }\end{array}$ & $\mathrm{P}>0,05$ & $\mathrm{H}_{0}$ Kabul \\
\hline 14 & $\begin{array}{l}\text { Özkaynak devir hızı dağılımı } \\
\text { gruplar arasında farklılık } \\
\text { göstermemektedir. }\end{array}$ & $\begin{array}{l}\text { Independent- } \\
\text { Samples Mann- } \\
\text { Whitney U Test }\end{array}$ & $\mathrm{P}>0,05$ & $\mathrm{H}_{0}$ Kabul \\
\hline 15 & $\begin{array}{l}\text { MDV devir hızı dağglımı } \\
\text { gruplar arasında farklılık } \\
\text { göstermemektedir. }\end{array}$ & $\begin{array}{l}\text { Independent- } \\
\text { Samples Mann- } \\
\text { Whitney U Test }\end{array}$ & $\mathrm{P}>0,05$ & $\mathrm{H}_{0} \mathrm{Kabul}$ \\
\hline 16 & $\begin{array}{l}\text { Dönen varlık devir hızı dağılımı } \\
\text { gruplar arasında farklılık } \\
\text { göstermemektedir. }\end{array}$ & $\begin{array}{l}\text { Independent- } \\
\text { Samples Mann- } \\
\text { Whitney U Test }\end{array}$ & $\mathrm{P}>0,05$ & $\mathrm{H}_{0}$ Kabul \\
\hline 17 & $\begin{array}{l}\text { Ort. etkinlik süresi dağılımı } \\
\text { gruplar arasında farkl1lık } \\
\text { göstermemektedir. }\end{array}$ & $\begin{array}{l}\text { Independent- } \\
\text { Samples Mann- } \\
\text { Whitney U Test }\end{array}$ & $\mathrm{P}>0,05$ & $\mathrm{H}_{0}$ Kabul \\
\hline 18 & $\begin{array}{l}\text { Brüt kâr marjı dağılımı gruplar } \\
\text { arasında farklılık } \\
\text { göstermemektedir. }\end{array}$ & $\begin{array}{l}\text { Independent- } \\
\text { Samples Mann- } \\
\text { Whitney U Test }\end{array}$ & $\mathrm{P}>0,05$ & $\mathrm{H}_{0}$ Kabul \\
\hline 19 & $\begin{array}{l}\text { Faaliyet kâr marjı dağılımı } \\
\text { gruplar arasında farklılık } \\
\text { göstermemektedir. }\end{array}$ & $\begin{array}{l}\text { Independent- } \\
\text { Samples Mann- } \\
\text { Whitney U Test }\end{array}$ & $\mathrm{P}<0,05$ & $\mathrm{H}_{0}$ Ret \\
\hline 20 & $\begin{array}{l}\text { Net kâr marjı dağılımı gruplar } \\
\text { arasında farklılık } \\
\text { göstermemektedir. }\end{array}$ & $\begin{array}{l}\text { Independent- } \\
\text { Samples Mann- } \\
\text { Whitney U Test }\end{array}$ & $\mathrm{P}<0,05$ & $\mathbf{H}_{0}$ Ret \\
\hline 21 & $\begin{array}{l}\text { Özkaynak kârlılığı dağılımı } \\
\text { gruplar arasında farklılık }\end{array}$ & $\begin{array}{l}\text { Independent- } \\
\text { Samples Mann- }\end{array}$ & $\mathrm{P}<0,05$ & $\mathbf{H}_{0}$ Ret \\
\hline
\end{tabular}




\begin{tabular}{|l|l|l|l|l|}
\hline $\mathbf{2 2}$ & göstermemektedir. & $\begin{array}{l}\text { Whitney U Test } \\
\text { Aktif kârlılığ dağılımı gruplar } \\
\text { arasında farkl1lık } \\
\text { göstermemektedir. }\end{array}$ & $\begin{array}{l}\text { Independent- } \\
\text { Samples Mann- } \\
\text { Whitney U Test }\end{array}$ & $\mathrm{P}<0,05$ \\
\hline $\mathbf{2 3}$ & $\begin{array}{l}\text { FVÖK / aktif toplamı dağılımı } \\
\text { gruplar arasında farklılık } \\
\text { göstermemektedir. }\end{array}$ & $\begin{array}{l}\text { Independent- } \\
\text { Samples Mann- } \\
\text { Whitney U Test }\end{array}$ & $\mathrm{P}<0,05$ & $\mathbf{H}_{\mathbf{0}}$ Ret \\
\hline
\end{tabular}

Bağımsız örneklemler için Mann-Whitney U testi sonuçları incelendiğinde, finansal açıdan başarısız olan işletmeler ile finansal açıdan başarısız olmayan işletmeler arasında anlamlı farklılık gösteren finansal oranların; 6, 7, 19, 20, 21, 22 ve 23. satırlarda yer alan duran varlıklar/özkaynaklar, faiz karşılama oranı, faaliyet kâr marjı, net kâr marjı, özkaynak kârlılığ1, aktif kârlılığı ve FVÖK/aktif toplamı oranları olduğu görülmektedir.

Likidite oranlarından herhangi birinin finansal açıdan başarısız olan ve finansal açıdan başarısız olmayan işletmelerde anlamlı bir farklılık göstermediği tespit edilmiştir. Finansal açıdan başarısız olan ve finansal açıdan başarısız olmayan işletmeler için sırayla cari oran ortalamas1 1,78 ve 2,51 olarak, likit oran ortalamas1 1,00 ve 1,99 olarak ve nakit oran ortalaması 0,33 ve 0,92 olarak hesaplanmıştır. Bu durum da finansal açıdan başarısız olan işletmelerde, başarısız olmayan işletmelere kıyasla daha fazla kısa vadeli yabancı kaynak kullanımı olduğunu göstermektedir.

Mali yapı oranlarından duran varlıklar / özkaynaklar ve faiz karşılama oranlarının finansal açıdan başarısız olan ve finansal açıdan başarısız olmayan işletmelerde anlamlı düzeyde bir farklılık gösterdiği tespit edilmiştir.

Duran varlıklar / özkaynaklar oranı ortalaması finansal açıdan başarısız olan işletmelerde 1,56 finansal açıdan başarısız olmayan işletmelerde ise 0,84 olarak hesaplanmıştır. $\mathrm{Bu}$ durum da finansal açıdan başarısız olan işletmelerde maddi duran varlıkların finansmanında yabancı kaynak kullanımın oldukça yoğun olduğunu, finansal açıdan başarısız olmayan işletmelerin özkaynaklarının da duran varlıkları finanse etmek için yeterli olduğunu ortaya çıkarmaktadır.

Faiz karşılama oran ortalamaları finansal açıdan başarısız olan işletmeler için -1,96 olarak finansal açıdan başarısız olmayan işletmeler için ise 1,43 olarak hesaplanmıştır. Bu durum da finansal açıdan başarısız olan işletmelerin esas faaliyetlerinden ve/veya yatırım faaliyetlerinden zarar ettiği anlamına gelmektedir

Faaliyet devir hızı oranlarından herhangi birinin finansal başarısızlı̆̆ın tahmin edilmesinde anlamlı bir farklılık göstermediği tespit edilmiştir. Ancak gruptaki finansal oranların ortalamalarına bakıldığında ortalama etkinlik süresinin finansal açıdan başarısız olan işletmelerde 235,21 gün, finansal açıdan başarısız olmayan işletmelerde ise 203,78 gün olduğu tespit edilmiştir. Her iki grubun ortalama tahsilat süresi oranı ortalamaları arasında yaklaşık 8 gün fark olmasına rağmen ortalama stokta kalma süresi oranı ortalamasının 
finansal açıdan başarısız olan işletmelerde finansal açıdan başarısız olmayan işletmelerden yaklaşık olarak 40 gün yüksek olduğu tespit edilmiştir. Bu durum da finansal açıdan başarısız olmayan işletmelerin alacaklarını daha çabuk tahsil ettiği ve stoklarını daha çabuk elden çıkardığı sonucunu ortaya koymaktadır.

Kârlılık oranlarından faaliyet kâr marjı, net kâr marjı, özkaynak kârlılığı, aktif kârlılı̆̆1 ve FVÖK/aktif toplamı oranlarının iki grup arasında anlamlı bir farklılık gösterdiği tespit edilmiştir. Finansal yapı oranlarında tespit edilen finansal başarısılık ile FVÖK ve özkaynaklar arasındaki ilişski kârlılık oranları ile de örtüşmektedir. Bu durum da finansal açıdan başarısız olan işletmelerde özkaynakların ve aktiflerin verimli kullanımı konusunda sıkıntılar yaşandığını ortaya çıkarmaktadır.

Sonuç olarak, hisseleri BİST'te işlem gören dokuma, giyim eşyası ve deri işletmelerinin finansal başarısızlıklarının ölçümlenmesinde duran varlıkar/özkaynaklar, faiz karşılama, faaliyet kâr marjı, net kâr marjı, özkaynak kârlılığı, aktif kârlılığı ve FVÖK/aktif toplamı oranlarından yararlanılabileceği tespit edilmiştir. Yapılan sınıflandırma analizi sonucunda, kullanılan diskriminant modelinin doğru sınıflandırma başarısı \%92 olarak hesaplanmıştır.

\section{SONUÇ}

Bu çalışmada 2013 yılında hisseleri BİST’te işlem gören dokuma, giyim eşyası ve deri işletmelerinin finansal oranları incelenerek söz konusu sektörde faaliyet gösteren finansal açıdan başarısız olan işletmeler ile finansal açıdan başarısız olmayan işletmelerin finansal oranları arasında anlamlı bir fark olup olmadığının tespit edilmesi amaçlanmıştır.

Çalışmaya konu olan sektörde toplam 27 işletme olmasına rağmen, Arbul Entegre Tekstil İşletmeleri A.Ş. hisselerinin 2014 yılı başında BİST’te işlem görmeye başladığı ve Gimsan Gediz İplik ve Mensucat Sanayi A.Ş. faaliyetlerinin 2010 yılında durdurulduğu tespit edilmiş ve bu sebeple söz konusu iki işletme veri setinden çıkartılarak çalışmaya toplam 25 işletme dahil edilmiştir.

Çalışmada işletmelerin finansal açıdan başarısız veya finansal açıdan başarısız olmayan işletmeler olarak sınıflandırılması için Altman Z Skoru ve ilgili yıl zarar beyan etme kıstasları göz önünde bulundurulmuştur. Bu bağlamda, Altman Z Skoru 1,81'in altında olan ve/veya ilgili yıl zarar beyan etmiş olan işletmeler finansal açıdan başarısız olarak sınıflandırılmıştır. Buna paralel olarak, Altman Z Skoru 1,81 ve üzerinde olan ve ilgili yıl kâr beyan etmiş ya da kâr veya zarar beyan etmemiş olan işletmeler ise finansal açıdan başarısız olmayan işletmeler olarak sinıflandırılmıştır. Bu sınıflandırma sonucunda ise 14 işletme finansal açıdan başarısız, 11 işletme ise finansal açıdan başarısız olmayan işletmeler grubuna aktarılmıştır.

Analiz sonuçlarına göre; duran varlıklar/özkaynaklar, faiz karşılama, faaliyet kâr marjı, net kâr marjı, özkaynak kârlılığı, aktif kârlılığı ve FVÖK/aktif toplamı oranlarının finansal açıdan başarısız olan işletmeler ile finansal açıdan başarısız olmayan işletmeler 
arasında anlamlı farklılık gösterdiği tespit edilmiştir. Kullanılan diskriminant modelinin doğru sınıflandırma başarısı \%92 olarak hesaplanmıştır. Sınıflandırma analizi sonuçları Tablo 4'te verilmiştir. $\mathrm{Bu}$ sonuç da kullanılan modelin finansal başarısızlık ölçümlemesinde yararlanılacak etkin bir model olduğunu göstermektedir.

Tablo 4. Sinıflandırma sonuçları

\begin{tabular}{|c|c|c|c|c|c|}
\hline \multicolumn{5}{|c|}{ Sinıflandırma Sonuçları } \\
\hline & Grup & Tahmin Edilen Grup Üyeliği & Toplam \\
\cline { 3 - 6 } & Miktar & 0 & 0 & 1 & 14 \\
\hline \multirow{2}{*}{$\begin{array}{c}\text { Orijinal Grup } \\
\text { Üyeliği }\end{array}$} & Yüzde & 0 & 12 & 11 & 11 \\
\hline & $(\%)$ & 1 & 0,0 & 14,3 & 100,0 \\
\hline
\end{tabular}

Çalışmanın sonucunda finansal oran verileri ile yapılan diskriminant analizi sonucundaki tespitleri daha da kuvvetlendirmek amacıyla dokuma, giyim eşyası ve deri sektörüne ait bilanço ve gelir tablosuna da diğer bir analiz tekniği olan dikey analiz tekniği uygulanmıştır. Sektör mali tabloları dikey analiz özetleri Tablo 5 ve Tablo 6'da yer almaktadır.

Tablo 5. BİST Dokuma, Giyim Eşyası ve Deri Sektörü Bilançosu dikey analiz özeti ${ }^{1}$

\begin{tabular}{|l|r|r|}
\hline Gruplar & Tutar (‡) & Genel Toplam \% \\
\hline Dönen Varlıklar & 3.040 .145 .563 & 46,67 \\
\hline Duran Varlıklar & 3.474 .282 .342 & 53,33 \\
\hline Aktif Toplamı & $\mathbf{6 . 5 1 4 . 4 2 7 . 9 0 5}$ & $\mathbf{1 0 0 , 0 0}$ \\
\hline Kısa Vadeli Yabancı Kaynaklar & 2.273 .421 .501 & 34,90 \\
\hline Uzun Vadeli Yabancı Kaynaklar & 892.198 .480 & 13,70 \\
\hline Özkaynaklar & 3.348 .807 .924 & 51,40 \\
\hline Pasif Toplamı & $\mathbf{6 . 5 1 4 . 4 2 7 . 9 0 5}$ & $\mathbf{1 0 0 , 0 0}$ \\
\hline
\end{tabular}

Sektörün varlık dağılımına bakıldığında dönen varlıkların genel toplam içinde \%47 duran varlıkların ise \%53'lük bir paya sahip olduğu görülmektedir. Söz konusu sektör için bu varlık dağılımı olumsuz bir durumdur. Genelde üretim işletmelerinde duran varlıkların özkaynaklarla finanse edilmesi ve genel toplam içinde $\% 65$ 'in üzerinde bir paya sahip olması arzu edilen bir durumdur.

\footnotetext{
${ }^{1}$ Uluslararası Finansal Raporlama Standartları’na göre düzenlenmiş ve Kamuyu Aydınlatma Platformu internet sitesinden alınmış olan özet finansal tablolardan oluşturulmuştur.
} 
Dönen varlık toplamının \%85'i, aktif toplamının ise \%40'1 stoklar ve kısa vadeli alacaklardan oluşmaktadır. Bu ise olumsuz bir durumdur. Çünkü bu durum sektör dönen varlıklarının büyük kısmının stoklara bağlanmış, aynı zamanda kredili satış politikasının benimsenmiş olduğunu göstermektedir. Ülkemizdeki enflasyonist ortam, döviz kurundaki dalgalanmalar ve sektörün modaya endeksli olduğu düşünülecek olursa, stokların ve alacakların dönen varlıklarda bu ağırlıkta olması olumsuz bir durum yaratmaktadır.

Kısa vadeli yabancı kaynakların pasif toplamı içerisindeki payının \%35 ve uzun vadeli yabancı kaynakların payının da \%14 olduğu görülmektedir. Bu durum sektördeki işletmeler açısından olumsuzluk yaratmaktadır. Çünkü üretim işletmelerinde kullanılan kredilerin uzun vadeli yabancı kaynak grubundan olması genelde kabul görmüş bir yaklaşımdır. Ayrıca kısa vadeli yabancı kaynak kullanımı, üretim işletmelerine yüksek borçlanma maliyetleri getirir. $\mathrm{Bu}$ da işletmelerin kârlılığını azaltıcı ve işletmeleri sermaye yetersizliğine taşıyan bir durumdur. Aynı zamanda sektörün varlıkların finansmanında yaklaşık olarak \%50 oranında yabancı kaynaklara yönelmiş olması ve yabancı kaynak ile finansmanın da işletmelere faiz yükü getiriyor olması sektör için bir olumsuzluk olarak karşımıza çıkmaktadır. İşletmelerin bu olumsuzluğu giderebilmesi için daha ucuz finansman kaynağı yaratması ve otofinansmana yönelmesi önerilir.

Sektör ortalama brüt kâr marj1 \%19 iken faaliyet kâr marjının \%5 olması sektördeki işletmelerin faaliyet giderlerinin yüksek olduğunu göstermektedir. $\mathrm{Bu}$ da ayrı bir olumsuzluk olarak karşımıza çıkmaktadır. Diğer bir ifade ile işletme ana faaliyet konusundaki satış faaliyetlerinden gelen kârlılığının \%14'ünü faaliyet giderlerinde eritmekte ve ana faaliyet konusundan gelen kârlılığını azaltmaktadır. Faaliyet giderleri içerisindeki en büyük kalemin ise \%9 ile pazarlama, satış ve dağıtım giderleri olduğu görülmektedir. Bu ise sektördeki işletmelerin rekabet güçlerini arttırma yönünde pazarlama, satış ve dağıtım faaliyetlerine ağırlık verdiğini göstermektedir.

Kısa vadeli finansal borçların £1.256.866.316 ve dönem faiz giderinin €350.787.511 olduğu göz önünde bulundurulursa faiz oranı yaklaşık olarak yıllık \%38 olarak hesaplanmaktadır. Bu da sektör işletmelerinin yüksek maliyetlerle krediler kullandığı ve yüksek borçlanma maliyetlerine katlandığının bir göstergesidir. Oysa ülkemizde devlet borçlanma faiz oranı $\% 11,75$ 'tir.

Tablo 6. BİST Dokuma, Giyim Eşyası ve Deri Sektörü Gelir Tablosu dikey analiz özeti ${ }^{2}$

\begin{tabular}{|l|r|r|}
\hline Gruplar & Tutar (f) & Genel Toplam \% \\
\hline Satıs Gelirleri & $\mathbf{4 . 5 4 1 . 4 0 3 . 0 5 1}$ & $\mathbf{1 0 0 , 0 0 \%}$ \\
\hline Satışların Maliyeti (-) & -3.718 .239 .914 & $-81,87 \%$ \\
\hline Brüt Kar (Zarar) & 835.822 .058 & $18,40 \%$ \\
\hline Faaliyet Karı (Zararı) & 222.745 .040 & $4,90 \%$ \\
\hline
\end{tabular}

\footnotetext{
${ }^{2}$ Uluslararası Finansal Raporlama Standartları'na göre düzenlenmiş ve Kamuyu Aydınlatma Platformu internet sitesinden alınmış olan özet finansal tablolardan oluşturulmuştur.
} 


\begin{tabular}{|l|r|r|}
\hline Sürd. Faal. Vergi Öncesi Karı (Zararı) & 21.972 .131 & $0,48 \%$ \\
\hline Sürd. Faaliyetler Dönem Karı/Zararı & -11.271 .199 & $-0,25 \%$ \\
\hline Dönem Karı (Zararı) & $\mathbf{- 1 1 . 2 7 1 . 1 9 9}$ & $\mathbf{- 0 , 2 5 \%}$ \\
\hline
\end{tabular}

Analiz sonucunda finansal açıdan başarısız olan işletmelerin, özellikle özkaynaklar ve aktifler ile ilgili finansal oranlarda, finansal açıdan başarısız olmayan işletmelerden ayrıldığ görülmektedir. Ayrıca, finansal açıdan başarısız olan işletmelerin birçoğunda brüt kâra ulaşılmış olmasına rağmen faaliyet zararının ortaya çıktığı görülmüştür. Aynı zamanda finansal açıdan başarısız olan işletmelerin faiz ödeme güçlerinin de oldukça düşük olduğu tespit edilmiştir. Sektör finansal tablolarından yararlanılarak yapılan dikey analiz sonuçları da diskriminant analizi ile ulaşılan sonuçları desteklemektedir. Tüm bu durumlar göz önünde bulundurularak, söz konusu işletmelerde finansal başarısızlığın ortaya çıkmasında aşağıdaki etkenlerin önemli rol oynadığı söylenebilir:

- $\quad$ Faaliyet giderlerinin -özellikle pazarlama, satış ve dağıtım giderlerinin- çok yüksek olduğu görülmektedir.

- Duran varlıklar/özkaynaklar oranının finansal açıdan başarısız olan işletmelerde 1,56 finansal açıdan başarısız olmayan işletmelerde 0,84 olması, finansal açıdan başarısız olan işletmelerin duran varlık yatırımlarında yabancı kaynaklardan yüksek ölçüde yararlanıldı̆̆ını göstermektedir.

- Duran varlıklar/özkaynaklar oranı ve faiz karşılama oranı birlikte değerlendirildiğinde finansal açıdan başarısız olan işletmelerin aşırı derecede borçlandıkları ve ucuz finansman sağlayamadıkları söylenebilir.

- $\quad$ Finansal açıdan başarısız olan işletmelerde aktif kârlılığı ve FVÖK/aktif toplamı oranlarının negatif çıkması işletme varlıklarının etkin biçimde kullanılamadığını göstermektedir.

- $\quad$ Faaliyet kâr marjı ile net kâr marjı arasında büyük fark olması, esas faaliyet alanı dışındaki faaliyetlerin işletmeye ek maliyet çıkardığını göstermektedir.

Yukarıdan belirtilen finansal başarısızlık nedenleri göz önünde bulundurulursa, finansal başarısızlığa düşen Dokuma, Giyim Eşyası ve Deri İşletmeleri için çözüm önerileri aşağıdaki gibi sıralanabilir:

- $\quad$ Elde tutulan stok miktarı minimum seviyede olmalı ve işletmeler optimum stok miktarını hesaplayarak daima etkin bir stok kontrol mekanizması kurmalıdır. Bu bağlamda işletmeler elde stok bulundurma maliyetlerini azaltacak ve modaya endeksli ürünlerdeki değer düşme risklerini önlemeye çalışacaktır.

- $\quad$ Borçlanma yerine hisse senedi ihracı yapılarak veya alacaklılara alacaklarına istinaden ortaklık payı verilerek özkaynaklar güçlendirilebilir. 
- İşletmelerde kullanılmayan ve/veya hurdaya ayrılmış olan duran varlıklar satılarak nakde dönüştürülebilir. Sektördeki işletmelerin üretim işletmesi olduğu düşünüldüğünde, dönen ve duran varlık dağılımının bir üretim işletmesine uygun olarak yapılandırılması gerekir. Bu da duran varlıkların toplam varlıklar içerisinde \%50'nin üzerinde bir paya sahip olmasını gerektirir.

- $\quad$ Sektördeki işletmeler geleceğe yönelik yatırım kararları alırken, bu kararların kârlı oldukları alanlarda ve ana faaliyet konuları ile ilgili alanlarda olması gerektiğini göz önünde bulundurmalıdırlar.

- Duran varlıkların finansmanında yüksek oranda özkaynaklardan yararlanılarak, özkaynakların yetersiz kalması durumunda uzun vadeli yabancı kaynak kullanımına gidilebilir. Ancak bu uzun vadeli yabancı kaynak kullanımında düşük faizli kredilerin kullanılması tercih edilmeli ve bu alternatifler aranmalıdır.

\section{KAYNAKLAR}

Akkaya, G. Cenk.- Tükenmez, N. Mine (2013). “İşletmelerde Finansal Yeniden Yapılanma Dinamikleri: Örnek Olay Analizi”, Dokuz Eylül Üniversitesi İktisadi ve İdari Bilimler Fakültesi Dergisi, Cilt 22, Sayı 2, Temmuz, s. 179-195.

Aktaş, Ramazan (1993). Endüstri İşletmeleri İçin Mali Başarısızlık Tahmini (Çok Boyutlu Model Uygulaması), Türkiye İş Bankası Kültür Yayınları, Ankara.

Aktaş, Ramazan.- Doğanay, Mete.- Yıldız, Birol (2003). "Mali Başarısızlığın Öngörülmesi: İstatistiksel Yöntemler ve Yapay Sinir Ağı Karşılaştırması”, Ankara Üniversitesi Siyasal Bilgiler Fakültesi Dergisi, Cilt 58, Say1 4, s. 1-24.

Altman, Edward I. (1968). "Financial Ratios, Discriminant Analysis and The Prediction of Corporate Bankruptcy”, The Journal of Finance, Cilt 23, Say1 4, Eylül, s.589-609.

Altunöz, Utku (2013). "Bankaların Finansal Başarısızlıklarının Yapay Sinir Ağları Modeli Çerçevesinde Tahmin Edilebilirliği”, Dokuz Eylül Üniversitesi İktisadi ve İdari Bilimler Fakültesi Dergisi, Cilt 28, Sayı 2, Temmuz, s.189-217.

Beaver, William H. (1966). "Financial Ratios as Predictors of Failure", Journal of Accounting Research, No. 4, p.71-111.

Blum, Marc (1974). "Failing Company Discriminat Analysis", Journal of Accounting Research, Vol 12, No 1, Spring, p. 1-25.

Büker, Semih.- Sevil, Güven.- Aşıkoğlu, Hasan Rıza (1997). Finansal Yönetim, 2. Bask1, Anadolu Üniversitesi Kütüphane ve Dokümantasyon Merkezi, Eskişehir.

Kurtaran Çelik, Melike (2010). "Bankaların Finansal Başarısızlıklarının Geleneksel ve Yeni Yöntemlerle Öngörüsü”, Celal Bayar Üniversitesi Yönetim ve Ekonomi Dergisi, Cilt 17, Sayı 2, Temmuz, s. 129-143. 
Deakin, Edward B. (1972). "A Discriminant Analysis of Predictors of Business Failure", Journal of Accounting Research, Vol 10, No 1, Spring, p. 167-179.

Edminister, Robert O. (1972). "An Empirical Test of Financial Ratio Analysis of Small Business Failure Prediction". Journal of Financial and Quantitative Analysis, Vol 7, No 2, p. 1477-1493.

Hill, Nancy Thorley.- Perry, Susan E. (1996). "Evaluating Firms İn Financial Distress: An Event History Analysis", Journal of Applied Business Research, Vol 12, No 3, p.6071.

İçerli M. Yılmaz.- Akkaya, G. Cenk (2006). "Finansal Açıdan Başarılı Olan İşletmelerle Başarısız Olan İşletmeler Arasında Finansal Oranlar Yardımıyla Farklılıkların Tespiti”, Atatürk Üniversitesi İktisadi ve İdari Bilimler Dergisi, Cilt 20, Say1 1, Nisan, s. 413-421.

Karacan, Sami.- Savcı, Mustafa (2011). "Kriz Dönemlerinde İşletmelerin Mali Başarısızlık Nedenleri”, Kocaeli Üniversitesi Sosyal Bilimler Enstitüsü Dergisi, Cilt 21, Say1 1, Aralık, s.39-54.

Lin, Tzong Huei (2009). "A Cross Model Study of Corporate Financial Distress Prediction in Taiwan: Multiple Discriminant Analysis, Logit, Probit And Neural Networks Models", Neurocomputing, Vol 72, No 16, p.3507-3516.

Özdemir, Fevzi Serkan.- Choi, Frederick D. S.- Bayazitll, Ercan (2012). "Finansal Başarısızlık Tahminleri Yönüyle UFRS ve Bilginin İhtiyaca Uygunluğu", Mali Çözüm. Sayı 112, Temmuz, s.17-52

Terzi, Serkan (2011). "Finansal Rasyolar Yardımıyla Finansal Başarısızlık Tahmini: Gıda Sektöründe Ampirik Bir Araştırma, Çukurova Üniversitesi İktisadi ve İdari Bilimler Fakültesi Dergisi”, Cilt 15, Sayı 1, Haziran, s. 1-18.

Sanayi Genel Müdürlüğü (2013). Tekstil, hazır giyim ve deri sektörleri raporu, T.C. Bilim, Sanayi ve Teknoloji Bakanlığı, Ankara.

Usta, Öcal (2005). İşletme Finansı ve Finansal Yönetim, Detay Yayıncılık, Ankara.

Uzun, Emin (2005). “İşletmelerde Finansal Başarısızlı̆ıı Teorik Olarak İrdelenmesi", Muhasebe ve Finansman Dergisi, Sayı 27, Temmuz, s. 158-168.

Wilcox, Jarrod(1970). "A Simple Theory of Financial Ratios as Predictors of Failure", Çalışma

Kâğıd1, Alfred P. Sloan School of Management, Aralık. http://dspace.mit.edu/bitstream/handle/1721.1/49121/simpletheoryoffi00wilc.pdf (23.09.2014) 